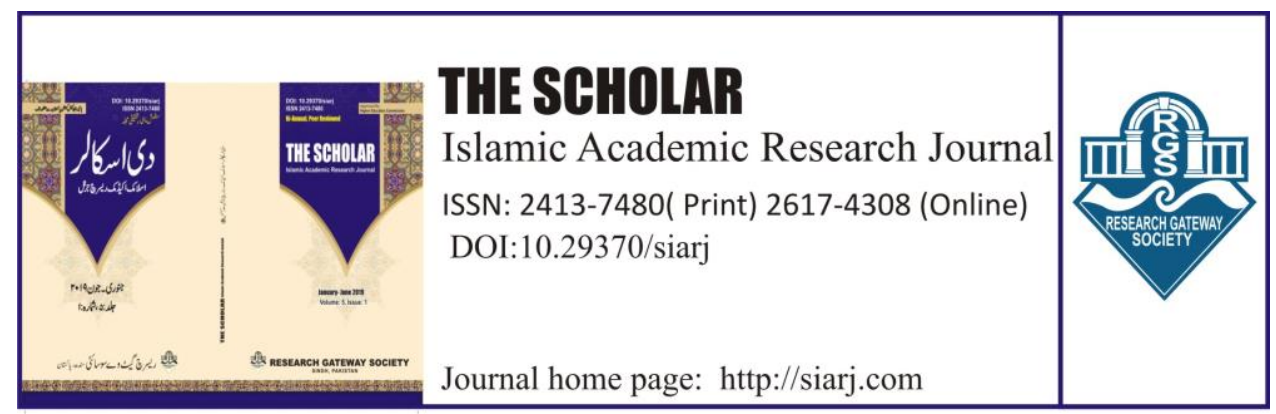

\title{
WAHBAH AL-ZUHAYLĪ'S INTELLECTUAL HERITAGE: A DISCOURSE ANALYSIS
}

\section{H. Syed Hamid Farooq Bukhari}

Lecturer, Department of Islamic Studies, University of Gujrat, Gujrat. PhD Scholar, Department of Arabic and Islamic Studies, GC University, Lahore.

Email: $\underline{\text { hamid.farooq@uog.edu.pk }}$

ORCID ID

\section{https://orcid.org/0000-0001-8084-8439}

To cite this article:

Bukhari, H. Syed Hamid Farooq. "ENGLISH- WAHBAH AL-ZUHAYLI' S

INTELLECTUAL HERITAGE: A DISCOURSE ANALYSIS.” The Scholar-Islamic Academic Research Journal 5, no. 1 (March 13, 2019): 93-112.

To link to this article:

https://doi.org/10.29370/siarj/issue8ar12

$\begin{array}{ll}\text { Journal } & \begin{array}{l}\text { The Scholar Islamic Academic Research Journal } \\ \text { Vol. 5, No. } 1 \text { || January -June 2019 || P. 93-112 } \\ \text { Research Gateway Society } \\ \text { Publisher }\end{array} \\ \begin{array}{l}\text { DOI: } \\ \text { URL: }\end{array} & \text { https://doi.org/10.29370/siarj/issue8ar12 } \\ \text { License: } & \text { Copyright c 2017 NC-SA 4.0 } \\ \text { Journal homepage } & \text { www.siarj.com } \\ \text { Published online: } & 2019-03-13\end{array}$

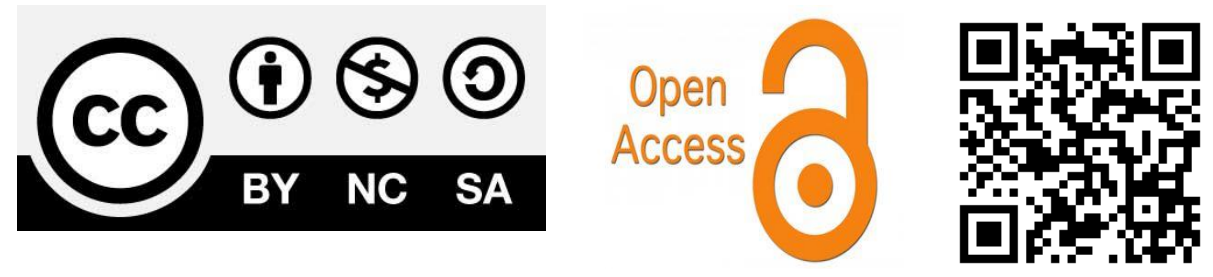


THE SCHOLAR (January - June 2019)

\title{
WAHBAH AL-ZUHAYLİ'S INTELLECTUAL HERITAGE:
}

\section{A DISCOURSE ANALYSIS}

H. Syed Hamid Farooq Bukhari

\begin{abstract}
:
Wahbah Al-Zuhaylī (1932-2015) has widely and impressively enhanced Islamic laws and legitimate jurisprudential through a lot of his addresses and his books which bargain comprehensively with different implications for Islamic societies. Most of all, his preaching as erudite and par excellences scholar on many topics of relevance of Muslims, not only in Middle East but all over the world. He contended that religious impulse to take after Sunni decrees is not mandatory for dependable, this current faction's constituents are allowed to take after four approved Sunni declarations, and even this is not necessary as long as one resembles skillful Islamic legal adviser. This is not religiously official but rather steadfast need to look like the lessons of Islamic scholars, particularly when one is not clear of the laws. Zuhaylī's intellectual work focuses on Comparative Islamic Jurisprudence, The revival of Islamic Jurisprudence, Principles of Islamic Jurisprudence and Quranic Jurisprudential Exegesis. He also clarifies the highlights of observation for reestablishment wanted, and the statement of reasons and motivations behind renewal in the process of contemporary jurisprudence. Zuhayli communicates his sentiment in contemporary law and proposes a picture of the implementation hoped renewal.
\end{abstract}

KEYWORDS: Contemporary, Islamic Jurisprudence, Tafsīr, Wahbah AlZuhạlī 


\section{INTRODUCTION:}

Dr. Wahbah Al-Zuhayli is considered to be as one of the prominent Sharī'ah and Islamic Finance scholars. He has a marvelous history of his enormous academic career, which illustrates his deep intellect about Shari' 'ah and also, his personality. Moreover, the whole world has acclaimed his acumen on contemporary issues. Having in-depth insight into Islamic Laws led him to write a lot of precious books. His books have played a significant role in academic field and also are included in the syllabus of different faculties. It is important to understand his life in the perspective of his academic work, before proceeding further into the analytical research work.

\section{ZUHAYLĪ'S BIRTH AND EDUCATION:}

Wahbah al-Zuhaylī (1932-2015) was born in "Deir "Ațiyah" region of Syria. ${ }^{1}$ Deir 'Ațiyah or Dayr 'Ațiyah is a city in Syria, situated between the Qalamoun Mountains and the Eastern Lebanon Mountains Series, 88 kilometers north of the Damascus and making a course for the city of Homs. His Father, Muṣtafā al-Zuhaylī, made his employment as a Businessman as well as a farmer. Wahbah obtained his essential education inside the area of "Deir "Ațiyah"; afterwards he traveled to the center and chose the "University of Damascus"2. Damascus University is not only the biggest of five institutions in the Syrian Arab Republic, but also the most seasoned one for its rich scholastic traditions. In 1952, Zuhaylī passed from the Sharī'ah faculty at "University of Damascus" with an excellent grade. He completed his degree from "Al-Azhar University" with

\footnotetext{
${ }^{1}$ Wahbah Al-Zuhaylī, Al-Tafsīr al-Munīr (Dār al-Fikar, Wahbah Al-Zuhaylī, 1991).

${ }^{2}$ Umar Bakrī Muhammad, Al-Maktabah Jāmi'ah (University of Damascus Alumni, 2010).
} 
$\overline{\text { distinction in } 1956 .{ }^{3} \text { Zuhaylī as well joined "Ain Shams University" Cairo, }}$ in 1957 and graduated later in the year. ${ }^{4}$ University of Ain Shams was built in 1950 and it is the third most important academic institution in Egypt.

In 1959, he acquired his Masters level in Law from "Cairo University". He attained his $\mathrm{PhD}$ in International law in the company of specialization in "Sharī'ah" four years later in 1963. ${ }^{5}$ Cairo University is Egypt's biggest state funded institution with its fundamental grounds in Giza. It was established on 21 December 1908. Zuhaylī's thesis focused on "The Influences of War in Islamic Jurisprudence: A comparative analysis including the eight schools of Islamic law and International law" under the guidance of Dr. Muhammad Sālam Madkūr . ${ }^{6}$

\section{ZUHAYYLİ'S TEACHERS:}

No human being can develop and grow until a teacher plays a crucial role in his development and improvement. Allah Almighty bestowed him the best ever teachers of that time. He was fortunate that he found the teachers who were outstanding in their respective fields. Some of them were the teachers of Sharī'ah and some others were the presidents of organizations working for the new solutions of contemporary issues.

\section{SYRIAN TEACHERS:}

Some of his teachers from Syria are as follows:

\section{Sheikh Muḥammad Hāshem Al-Rifā 'ĩ:}

The addressor of Jämi' ah Umavì and the founder of "Jami' yat-wa

\footnotetext{
${ }^{3}$ Aḥmad Yāsīn, Maktabah Al-Qāhira (Al-Azhar University Alumni, 2011).

${ }^{4}$ Jamāl Badāwī, Ain Shams University Alumni (University Press, 2010).

${ }^{5}$ Donald Malcolm Reid, Cairo University and The Making of Modern World (University Press, 2002).

العام الدولي و القانون الثمانية المذاهب بين مقارنة در اسة ـ الإسلامي الفقه في الحرب آثار 6.
} 
tehzīb wa-ta 'lìm" (Organization of education and training). Presenting true picture of Islām was the Hallmark of Al-Zuhaylī which he learned from Sheikh M. Hāshem. ${ }^{7}$

\section{Sheikh 'Abdul Razzāq:}

$\mathrm{He}$ is a prominent Jurist from Syria who was the in charge of the house of Jurisdiction/Fatwā in democratic Syria. He taught Al-Zuhaylī the intricate philosophy of jurisprudence.

\section{Sheikh Muḥammad Yäsīn:}

He is the master of Language and Hadith sciences. The founder of the following organizations:

1. Jami 'yat Nahd 2. Jami 'yat 'Ulemā' 3 3. Jami' yat Al Hidāya Al Islāmia

Al-Zuhaylī got the knowledge of Hadìth science from him. ${ }^{8}$

\section{Sheikh Hassan Al-Shați:}

He is a scholar of Hanbali School of law and the first principal of Sharī'ah faculty at Damascus University. He was instrumental to instill in AlZuhaylī the love of 'Ilm ul farā'd and Ahwāl-e-Shakhṣiah

\section{Sheikh Hassan Habanakah Al-Meydānī:}

$\mathrm{He}$ is one of the great scholars of Damascus having enormous academic thought. One of the founders of:

1. Al-Madrasah Rehāniyah

2. Al-Ma 'had Al-Shar'

\footnotetext{
${ }^{7}$ Ja'far and Abdul Ghafūr, Al-Tafsīr Wal Mufasrūn Fī Thaubi Hī al Jadīd (Cairo, 778th ed, 2007).

${ }^{8}$ Badī'Sayed and Al-Ḥām, Wahbah Al-Zuhaylī al- Faqīh al- Mufassir.
} 
3. Jami 'yat Tojīh Al-Islāmī

4. Rābiṭa Al-'Ālam Al-Islāmī

Al-Zuhaylī received the knowledge of Interpretation from him. ${ }^{9}$

\section{Sheikh Șādiq Habanakah:}

$\mathrm{He}$ is the brother of Hassan Habanakah Al-Meydānī. Al-Zuhaylī gained from him the lesson of Interpretation.

\section{Sheikh Ṣālīh Al Falfūr:}

He is the founder of "Jami 'yat Al-Fath Al-Isläm $\vec{\imath}$ " as well as one of the famous Islamic educationist. He taught Al-Zuhaylī, Arabic Studies, literature and Blāghat.

\section{Sheikh Muhammad Lutfì Al-Fayūmī:}

He is renowned scholar who belongs to Hanbali Jurisprudence and he is the best ever teacher who educated Al-Zuhaylī Islamic Jurisprudence and Hadīth sciences.

\section{Sheikh Mahmūud Al-Rankūsī:}

Al-Rank $\bar{u} s \bar{\imath}$ is one of the famous, pious and prominent Muslims scholars and he is the principal of Dār Al-Hadìth Al-Ashrafia. Moreover, he is the president of "Rābita al- 'Ulemā". He imparted the knowledge of AlZuhaylī 'Aqāid and 'Ilm-e-kalām. ${ }^{10}$

\section{EGYPTIAN TEACHERS:}

Some of his teachers of Egypt are as follow:

\section{Sheikh Muhammad Abū Zuhra:}

He is a great Jurist, an eminent Imām of his era and authenticated

\footnotetext{
${ }^{9}$ Wahbah Al-Zuhạlī (n 1).

${ }^{10}$ Al-Ayāzī and Syed Muḥammad 'Al̄̄, Al-Mufasirun Hayatuhum Wa Manhajuhum, vol 624.
} 
Muslim Scholar of his time. Al-Zuhaylī bears a great influence from him in his personality and books. ${ }^{11}$

\section{Sheikh Mahmūud Shaltūt:}

Shaltüt is a great Jurist and reformer. Furthermore, he is the founder of "Majma 'Al-Baḥuth al-Islāmia".

\section{Sheikh'Abdul Rehmān Al-Tãj:}

He was Sheikh Al-Azhar from 1954 to 1958 and Al-Zuhaylī learned a lot from him regarding administration as well as contemporary issues.

\section{Sheikh 'īsā Manūn:}

He worked as a lecturer in Al-Azhar University and became a member of the organization of prominent Jurists. Additionally, he did his good job as the principal of Ușül-ud-dīn and Shari' 'ah faculty as well.

\section{Sheikh Muhammad 'Alī Al-Khafìf:}

Al-Khafif is one of the scholars of Jurisprudence and Islamic law in Egypt. He wrote more than ten books in Jurisprudence and its principles. He also composed a number of articles in different subjects. $^{12}$

Al-Zuhaylī once remarked that he has earned knowledge from his Egyptian teachers and Taqwā from his Syrian teachers.

\section{ZUHAYLĪ'S CAREER:}

In proficient field, Zuhaylī has apprehended significant spots in elevated learning organizations. In 1963, Wahbah was preferred as an education assistant by the "Sharī'ah" personnel at "Damascus University"; furthermore, he assumed the office as "Vice Dean" of this University.

\footnotetext{
${ }^{11}$ Aḥmad b. Mạ̣mūd, Wahbah Al-Zuhạalī, vol 414 (Dār al-Fikar, 2007).

${ }^{12}$ Saiful Amin Ghofur, Mufassir Ul Qur'ān, vol 175 (Insan madni, 2007).
} 
Zuhaylī as well qualified in favor of two years like an imperative tutor by the law faculty at "Benghazi University" Libya In 1972. University of Benghazi is a state funded institution in Benghazi, Libya and it is a standout among the most vital organizations of advanced education in Libya. It is situated in Benghazi, the second biggest city in the nation. It was established on 1955 as the University of Libya.

At "United Arab Emirates University" For five years, he served as a member of staff of Law from 1984 to 1989. United Arab Emirates University (UAEU) Established in 1976 by "Sheikh Zayed Al Nahyān", UAEU tries to wind up an extensive, inquires about solemn college and right now enlists roughly 14,000 Emirati and worldwide students. Zuhaylī similarly worked in the position of eminent professor at the "Khartoum University", it is a multi-grounds, co-instructive, state funded university situated in Khartoum. It is the biggest and most established institution in Sudan. As well as Sudan International University was set up in the year 1990 as a private college situated in Khartoum, Sudan. It has been a focal point of fabulousness in giving diverse Post and Undergraduate courses and it's eminent for its scholastic brilliance and its worldwide principles.

Dr. Zuhaylī additionally educated the benchmarks of Islamic faithful creation along with authentication for graduate learners in "Sudan and Pakistan". In Pakistan, Especially in International Islamic University Islamabad, He visited many times and delivered scholarly lectures. Zuhaylī likewise provided his services as an associate of "Ahl al-Bai'yt Foundation" in Jordan for numerous years. The Royal Ahl al-Bai'yt Institute for Islamic Thought is a worldwide Islamic non-legislative, 
autonomous organization headquartered in Amman, Jordan. ${ }^{13}$

Zuhaylī put in his exertion like a significant affiliate of diverse "Fiqh academies" of different nations comprising the "Syrian Islamic Council, The Syrian Islamic Council which is proposing to twist up the principle resistance Sunni religious power for the country, held its inaugural meeting in Istanbul on April 11 and 12. It cases to address 40 of the religious gatherings and chambers that have mushroomed in the country and in the Diaspora since 2011. There are frequent further splendid career inside the "Shari'ah", they are: as the head of "Islamic Finance and Islamic banking organizations" as well as one of imperative folks of panel of "Sharī'ah Islamic Bank". ${ }^{14}$

Zuhaylī was a wonderful spiritual preacher within the Islamic globe. He used to appear on television as well as broadcasting projects. Zuhaylī was a priest along with member of the clergy at a "Mosque" in Damascus that is entitled "The Othman Mosque". At the same time, he served as a parson at a "Mosque" entitled "Badr Mosque" in "Dair "Ațiyah". It may be concluded that he served on various positions and contributed a lot for advancement of Islamic civilization. ${ }^{15}$

\section{ZUHAYLĪ'S DEATH:}

Such a great personality that can be equated with the likes of Ibn Qayyim, al-Nawawī, Ibn Kathīr and Sa 'ìd Ramḍ̄an al-Būṭī in terms of academic achievements and pursuit of left this fleeting world for his heavenly abode on the eighth of August 2015, Saturday, in Damascus. He has left a permanent legacy of intellectualism and authority to Islam. May Allah the

\footnotetext{
${ }^{13}$ Badī‘ Sayed Al-Hāam, Wahbah Al-Zuhaylī al- Faqīh al- Mufassir, vol 11.

${ }^{14}$ Hadād and jibrīl Fu'ād, Wahbah Al-Zuhaylī Sīratuhū, vol 25 (Dār al-Fikar, 2013).

${ }^{15}$ Badī‘ Sayed Al-Ḥām (n 13).
} 
Almighty give him His favors and the best of dwelling places in the Hereafter! Ameen!!

\section{ZUḤAYLĪ'S INTELLECTUAL HERITAGE:}

Al- Zuhaylī composed various books for the most part about Islamic law and Islamic legal philosophy. Among them are:

\section{COMPARATIVE ISLAMIC JURISPRUDENCE:}

Comparative Islamic Jurisprudence ${ }^{16}$ is intended to collect various legal opinions, evaluations and balancing them to seek evidence. There are four schools of thought inside Islamic Jurisprudence:

(i) Hanafi School of Thought

(ii) Mālikī School of Thought

(iii) $S h \bar{a} f^{\prime} \bar{\imath}$ School of Thought

(iv) Hanbali School of Thought ${ }^{17}$

Critical analysis of various Schools of Thought has grown significantly in present day age among Muslim researchers. In this module of study legal scholars attempt to fathom out essentially, key contracts and questionable cases in various sections of Fiqh. In the consequence of this, numerous books with respect to Comparative Study of Islamic law have surfaced. The most renowned of all these books is "Al-Fiqh al-Islami wa Adalituhu (Islamic Jurisprudence and its proofs)" by Wahbah al-Zuhaylī.

\section{“AL-FIQH AL-ISLAMĪ WA ADILATUHU” (الفقه الاسلامى و ادلثه):}

The most critical work of Zuhaylī's life comprises of eleven volumes called "Al-Fiqh al-Islamī wa Adalituhu". It truly is an interesting and

\footnotetext{
${ }^{16}$ Al-Jazīrī and Abdul Rehman, Al-Fiqh 'alā al-Madhahib al-Arb'ah.

${ }^{17}$ Hallaq and Wael, an Introduction to Islamic Law.
} 
The Scholar Islamic Academic Research Journal

Vol. 5, No. 1 || January-June 2019 || P. 93-112

https://doi.org/10.29370/siarj/issue8ar12

inimitable work on comparative jurisprudence. Independently the greatest offer in the old and modern history in the field of comparative jurisprudence is an awesome accomplishment and complete stockpiling and in its substance considered the second biggest accumulation in the field of Islamic Jurisprudence after "Al-Mūsū 'ah al-Fiqhia Kuwait" which is the upshot of Academy's attempts.

Zuhaylī covered in this masterpiece not only all the topics of Islamic Jurisprudence but also mentions different schools of Thought thoroughly. But four of the significant schools, he additionally examined conclusions

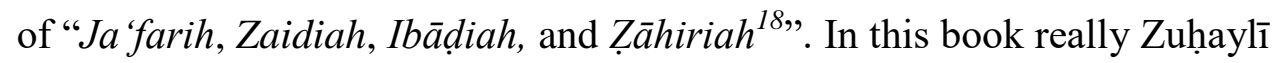
needs to illuminate us that nature of Islamic Jurisprudence is leniency so, if anyone finds easier and simple commands with strong arguments then there is no harm to follow up on other's Fiqh. Zuhaylī says even while staying on the "Taqli $d{ }^{19}$ we can gain from different factions and Schools of Thought.

Numerous Islamic Universities especially, in Pakistan and Sudan have made "Al-Fiqh al-Islami wa Adalituhu" some portion of their consistent educational modules because of given significance and utility to this book yet every Islamic Library graced itself with this book as a wellspring of Comparative Jurisprudence.

In this book Zuhaylī's order of the chapters is as follows:

First Chapter: $\quad$ Fiqh about Worship Matters

Second Chapter: Different Jurisprudential Theories

Third Chapter: $\quad$ Fiqh about Business Matters

Fourth Chapter: $\quad$ Fiqh about Ownership Matters

\footnotetext{
${ }^{18}$ Momen and Moojan, An Introduction to Shī'ah Islam (1985).

${ }^{19}$ Sharīf and Abū ' $\bar{A}$ liah, The Truth about Taqlid (The Jawziyyah Institute, 2007).
} 
The Scholar Islamic Academic Research Journal

Vol. 5, No. 1 || January-June 2019 || P. 93-112

https://doi.org/10.29370/siarj/issue8ar12

Fifth Chapter: General Jurisprudential Matters

Sixth Chapter: $\quad$ Fiqh about Family Matters

Seventh chapter: Contemporary Jurisprudential Matters

“AL-WAJĪZ FĪ AL-FIQH AL-ISLAMĪ” (الوجيز فى الفقه الاسلامى):

After "Al-Fiqh al-Islamī wa Adilatuhu" Zuhaylī made this book as a rundown of Islamic Jurisprudence on the grounds that everybody couldn't read that entire book so he outlined all the contentions here.

In this book, Zuhaylī attempted to specify "The Legal Text (Shar'ī $N a s ̦ \bar{u} s)^{\text {"21 }}$ in each Jurisprudential section then portray the issues with regards to these Legal Texts which is compulsory for each Muslim to act without wrong clarification. Zuhaylī additionally assembled The Qur'ānic verses and $A h \bar{a} \bar{d} \bar{t} t h$ in one place which is a new process as well as requires long tolerance and steady struggle.

In this book Zuhaylī's order of the chapters is as follows:

First Chapter: $\quad$ Fiqh about Worship Matters

Second Chapter: $\quad$ Fiqh about Business Matters

Third Chapter: $\quad$ Fiqh about Common Matters

Fourth Chapter: $\quad$ Fiqh about Family Matters

In this order Zuhayli only be satisfied on the evidence and arguments which are actually mentioned in the legal texts.

“'ĀTHĀR AL-HQ̣ARB Fī AL-FIQH AL-ISLAMĪ”(آثار الحرب في الفقه الإسلامي):22

Zuhaylī’s Ph.D. thesis entitled: "The Influences of War in Islamic

20 (Dār al-Fikar, 2007).

${ }^{21}$ Al-Zuhaylī, Uṣūl Al-Fiqh al-Islamī (Dār al-Fikar, 1986).

22 (Dār al-Fikar, 1963). 
The Scholar Islamic Academic Research Journal

Vol. 5, No. 1 || January-June 2019 || P. 93-112

https://doi.org/10.29370/siarj/issue8ar12

Jurisprudence: A comparative analysis including the eight schools of Islamic law and International law ( آثار الحرب في الفقه الإسلامي ـ دراسة مقارنة بين المذاهب "(الثمانية والقانون الدولي العام "showed respect around the World and immense scholars have paid tribute to him. This book on the subject is known as an authority, a comparative analysis and objective study of ancient and modern thoughts about war and peace have been a review in it. Famous jurist Yūsuf al-Qarḍāwī has called it an unprecedented book on the subject, he says:

"In this book, Wahbah al-Zuhaylī presented an exceptional selection of our extensive theological literature and we have had enough references and citations from this book and displayed in the book "Fiqh al-Jihād."23 This thesis, in fact, was the beginning of Zuhaylī’s scholastic and research journey which have been fixed in height subsequently and now Zuhaylī is the core name of Islamic Jurisprudence.

In this book Zuhaylī's order of the chapters is as follows:

First Chapter: $\quad$ Fundamental affects about War

Second Chapter: The influences about Rationalization of the War

Third Chapter: $\quad$ The influences about End of the War

\section{“AL-ALĀQĀT AL-DOWLIAH Fī AL-ISLĀM" (العلاقات الدولية فى الاسلام):24}

In this book, Zuhaylī endeavored to be characterized Islamic standards about global relations in war and peace. He exhibited detailed analysis of understandings as indicated by Islam in this book from the Jurisprudential

\footnotetext{
${ }^{23}$ Al-Qarḍ̄̄wī and Yūsuf, Fiqh Al-Jihād: Dirāsah Muqāranah Li-Aḥkāmih Wa Falsafatih F̄̄ Daw' al-Qur'ān Wa al-Sunnah (Maktabah Wahbah).

${ }^{24}$ (Muassasah al-Risalah, 1987).
} 
The Scholar Islamic Academic Research Journal

Vol. 5, No. 1 || January-June 2019 || P. 93-112

https://doi.org/10.29370/siarj/issue8ar12

perspective and historical point of view too. He depicted how it was actualized in the time of Prophet, in the time of Guided Khulafa $\bar{a}^{\prime}$ and in consequent periods. This book comprises of two sections and one comprehensive preamble.

In this book Zuhaylī's order of the chapters is as follows:

First Chapter: International Relations in Wartime

Second Chapter: International Relations in Peacetime

After a critical study of this book, it will be built up that previously, international relations amongst Muslims and Non-Muslims were not diverse as current age relations in their genuine spirit.

\section{THE REVIVAL OF ISLAMIC JURISPRUDENCE ${ }^{25:}$}

Islamic Jurisprudence has gone through various stages from the period of Compilation to the present. It has confronted various types of changes. The stylistics of composing of Islamic law has been additionally changing the course. The law specialists have assembled different juristic accumulations as indicated by the necessities of each age. Wahbah alZuhaylī is one of those prominent researchers who contributed their significant work with respect to the modernization of Islamic jurisprudence.

\section{“AL-FIQH AL-ISLAMĪ FĪ USLŪBIHI AL-JADĪD”: ${ }^{26}$}

Zuhaylī presents a comprehensive and live idea of Islamic Jurisprudence. He says that Fiqh is not restricted to some fundamental problems and issues but rather identified with each part of life. He likewise announces

\footnotetext{
${ }^{25}$ Al- ‘ṭiah and Jamāl al-Dīn, Tajdīd Al-Fiqh al-Islamī (Dār al-Fikar, 2012).

${ }^{26}$ Maktabah Al-Hadith (1967).
} 
The Scholar Islamic Academic Research Journal

Vol. 5, No. 1 || January-June 2019 || P. 93-112

https://doi.org/10.29370/siarj/issue8ar12

that there are some essential guidelines for Sharī'ah and Islamic Jurisprudence as a basic framework. In their light Islamic Jurisprudence and objectives of Sharī'ah can be assessed totally as indicated by advanced needs.

In this book Zuhaylī's order of the chapters is as follows:

First Chapter: $\quad$ Fiqh regarding Business Contracts

Second Chapter: $\quad$ Fiqh regarding Rent Contracts

Third Chapter: $\quad$ Fiqh regarding Companies Contracts

Fourth Chapter: $\quad$ Fiqh regarding Expiation and Vows

\section{“Tajdīd al-Fiqh al-Islami” (تجديد الفقه الاسلامى):27}

Actually, this book is a combination of discussions and exchange of views with Famous researcher Jamāl al-Dīn Al-'Ațiyah which comprise of imperative and key themes. This book is indented to depict modernization, its confinements, its system and its power in detail with all things. He also explains the features of perception for renewal desired, and the statement of reasons and purposes of renewal in the process of contemporary jurisprudence. Zuhaylī expresses his opinion in contemporary jurisprudence and suggests a picture of the implementation hoped renewal. In this book Zuhaylī's order of the chapters is as follows:

First Chapter: $\quad$ Al- 'Ațiyah's thought about revival of Fiqh

Second Chapter: Al-Zuhaylī’s thought about revival of Fiqh

\footnotetext{
${ }^{27}$ Dār Al-Fikar (2012).
} 
The Scholar Islamic Academic Research Journal

Vol. 5, No. 1 || January-June 2019 || P. 93-112

https://doi.org/10.29370/siarj/issue8ar12

PRINCIPLES OF ISLAMIC JURISPRUDENCE:28

The most key branch of learning in course of Islamic Jurisprudence is the principles of Islamic law, a delightful subject and anticipated by Muslims. The Principles of Jurisprudence is, in actuality, the "investigation of the standards to be utilized as a part of deriving the Islamic laws" and it shows us the right and legitimate method for finding from the important sources of law. Al-Zuhaylī also contributed his critical work as for principles of Islamic law.

\section{“UȘŪL AL-FIQH AL-ISLAMĪ” (اصول الفقه الاسلامى):29}

This is not only a book but also an encyclopedia regarding Principles of Islamic Jurisprudence. Zuhaylī’s this work is substantially more precise and scientific, it's a worthwhile effort to combine tradition and modernity. This leading book has been made part of the educational modules in a few Arab Universities especially, in Islamic University Madīnah and Riyad University the book is a part of the regular educational curriculum for higher studies. In India and Pakistan, several organizations and Institutions have incorporated this magnum opus in their educational programs and acknowledged it as a source of the perspective book.

In this book Zuhaylī’s order of the chapters is as follows:

This book consists of one preface and eight chapters.

First Chapter: $\quad$ Legal Rules

Second Chapter: $\quad$ Ways to elicit rules from Legal texts

\footnotetext{
${ }^{28}$ Kamālī and Hāshim, Principles of Islamic Jurisprudence (International Islamic University).

${ }^{29}$ Dār Al-Fikar (Beirut, 1986).
} 
The Scholar Islamic Academic Research Journal

Vol. 5, No. 1 || January-June 2019 || P. 93-112

https://doi.org/10.29370/siari/issue8ar12

Third Chapter: $\quad$ Sources of Legal rules

Fourth Chapter: Abrogation

Fifth Chapter: $\quad$ Interpretation of Legal texts

Sixth Chapter: $\quad$ Objectives of Sharī'ah

Seventh Chapter: $\quad$ Ijtihād and Taqlìd

Eighth Chapter: $\quad$ Conflict of Opinion and Preference

\section{JURISPRUDENTIAL QUR'ĀNIC EXEGESIS: ${ }^{30}$}

Famous exegete Al-Tabrī says in the preamble of his interpretation:

“The Holy Qur'ān is an ocean of boundless, profound Furthermore, not trimmed, loaded with pondering and uniqueness, will never decay with age and will not be devastated as a result of entertain, it's placed to thought for individuals who need to think, as a tough rope to the searching for hold altogether not to fall into the decimation". 31

There are numerous researchers who decipher al-Qur'ān since Khalīfah's time to the present one is Wahbah Zuhaylī. Indeed, even he is a specialist in Islamic Jurisprudence but his commitment in the field of Qur'ānic elucidation advantageous. Most contemporary Qur'ānic interpretations are from the different logical foundation; Wahbah Zuhaylī is a jurist attempting to decode al-Qur'ān verses by the sources, strategies, style, and particular qualities. In the field of exegesis, Zuhayli has three famous books named by "Tafsīr al-Wajīz, Tafsìr al-Wasìt, and Tafsīr al-Munīr". However, the most renowned is Tafsìr al-Munīr. This is apparent with these significant three books of incorporated Tafsìr; Zuhaylī is not just

${ }^{30}$ Al-Keyāhrāsī and Alī b. Muhammad, Ahkām Al-Qur'ān.

${ }^{31}$ Al-Ṭabrī and Ibn jarīr, Jāmi'al-Bayān F̄̄ T’wīl al-Qur'ān (Muassasah al-Risālah, 1420 A.H.). 
The Scholar Islamic Academic Research Journal

Vol. 5, No. 1 || January-June 2019 || P. 93-112

https://doi.org/10.29370/siarj/issue8ar12

specialists in the field of Fiqh but in Qur'ānic exegesis as well.

“TAFSĪR AL-MUNĪR" (التفسير المنير):32

This Qur'ānic exegesis “Tafsīr al-Munīr fì al-'aqīdah wa al-Sharī'ah wa al-Manhaj" is the greatest book arranged by Wahbah Zuhaylī. This interpretation is written in a traverse of 16 years subsequent to wrapping up composing two different books, to be specific "Ușūl al-Fiqh al-Islami and Al-Fiqh al-Islamī wa Adalituhu". Tafsīr al-Mun̄̄r is more extensive and that's only the tip of the iceberg definite exegesis than his others elucidations, portrays in detail the substance of each Qur'ānic Sūrah, containing the qualities Sürah based on the true portrayals and far from a frail history.

Zuhaylī declares objective behind this exegesis is:

'Muslims must hold strong to al-Qur'ān deductively, on the grounds that Holy Qur'ān involves life which is exceptionally useful, in general to all human beings and Muslims specifically". ${ }^{33}$

Zuhaylī in his exegesis depicts eventually about the issues of jurisprudence and laws which he evaluates from al-Qur'ān to clarify the assessment of renowned Islamic jurists. He similarly clarified the issues of aqĩdah, Akhlaq and Manhaj (Methodology) in offering rituals, Legal texts and rules generally, advantages or the privileged insights of the Qur'ānic verse, either articulate or disguised, either in relatively to the community or public life, or connected with personal life, whether associated with the

\footnotetext{
${ }^{32}$ Dār Al-Fikar (1991).

${ }^{33}$ Wahbah Al-Zuhaylī (n 1).
} 
The Scholar Islamic Academic Research Journal

Vol. 5, No. 1 || January-June 2019 || P. 93-112

https://doi.org/10.29370/siarj/issue8ar12

life of this fleeting world or the life of Hereafter. ${ }^{34}$

In this exegesis, Zuhaylī explains his method as follows:

1: Gathers group of verses in light of a subject went with by a reasonable presentation.

2: Presents a portrayal of each Sürah for the most part.

3: Gives a clarification of the dialect.

4: Clarifies consecutively verse with Asbāb al-nuzūl.

5: demonstrates the accounts of prophets and extraordinary Islamic occasions.

6: investigates legal jurisprudential laws of verses explained.

7: Interprets verses from Balāghat and I' $r a \bar{a} b .{ }^{35}$

Toward the end of the discourse, al-Zuhayli formulates conclusions verses, obviously, for this situation; it creates simple for the reader and reaches inferences to be connected in regular daily existence.

“TAFSīR AL-WASīṬ” (التفسير الوسيط):

This elucidation book is accumulations of his presentation through communicate media especially, for the Syrian populace and after that spread to numerous urban communities. Generally, his lecture displayed this Qur'ānic presentation at day break each day for six hours, but on Friday, he didn't show up in light caused by the holiday. This achievement keeps running for a long time, beginning from 1992 to 1998, after that, it is congregated into Qur'ānic exegesis.

This exegesis has two main characteristics: First, a sentence structure that

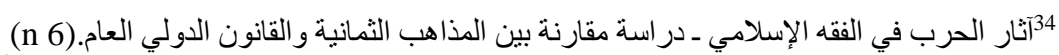

${ }^{35}$ Saiful Amin Ghofur (n 12).

${ }^{36}$ Dār Al-Fikar (Damascus, 2001). 
The Scholar Islamic Academic Research Journal

Vol. 5, No. 1 || January-June 2019 || P. 93-112

https://doi.org/10.29370/siarj/issue8ar12

is exact or exhaustive, sketching out every point or subject equitably on each part, clear and effectively comprehended by the pursuer and reader. Second, the enlightenment of the verse is simply derived from Asbāb annuzūl of genuine history. Zuhaylī truly sticks to Ușūl al-Tafsìr that has been endorsed by Mufasrīn, furthermore, allude to well-known exegesis books, and away from isrā'îliyāt.

\section{“TAFSīR AL-WAJ̄̄Z” (التفسير الوجيز):}

This Qur'ānic exegesis just depicts a little bit the importance of each verse, and it clarifies a few of words or sentences in al-Qur'an that according to Zuhaylī is extremely hard to comprehend by people. He also presents some information about Asbāb al-nuzūl with the significance of essential verses. Zuhaylî’s purpose to compile this book is to facilitate those people who still lay in comprehension the importance of Qur'ānic verses.

\section{CONCLUSION:}

After this discussion, it can be logically concluded that Wahbah alZuhaylī (1932-2015) is one of the Islamic researchers of profound information and considering, Zuhaylī is a cleric and preacher who lectured through in words and composed, either as books or articles. He is a specialist not only in the field of Islamic Jurisprudence but also as a

\footnotetext{
${ }^{37}$ Dār Al-Fikar (1996).
} 
The Scholar Islamic Academic Research Journal

Vol. 5, No. 1 || January-June 2019 || P. 93-112

https://doi.org/10.29370/siarj/issue8ar12

Qur'ānic exegete. Wahbah is not just known as a researcher additionally as

an Islamic thought whose his musings are genuinely straightforward; the primary purposes of his musings dispensed through text in the type of books which are beyond the total number of 133 with articles and papers surpasses 500 .

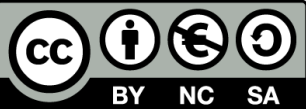

This work is licensed under a Creative Commons Attribution-NonCommercial-ShareAlike 4.0 International (CC BY-NC-SA 4.0) 